\title{
Impact of Generic Price Linkage System and Reference Price System on prices of pharmaceuticals - comparison of Austria and Finland
}

\author{
Jaana E Martikainen ${ }^{1 *}$, Timo Maljanen ${ }^{1}$, Hanna Koskinen', Sabine Vogler ${ }^{2}$ \\ From 3rd International PPRI Conference 2015: Pharmaceutical Pricing and Reimbursement Policies: Challenges \\ Beyond the Financial Crisis \\ Vienna, Austria. 12-13 October 2015
}

\section{Background}

To contain costs of medicines, many countries have introduced policies aiming to lower prices of generics [1]. Measures taken in Austria include Generic Price Linkage and in Finland Generic Substitution and Reference Pricing, where competition plays a crucial role.

\section{Objectives}

The aim of this study is to assess the Generic Price Linkage system and the system that includes Generic Substitution and Reference Pricing by comparing prices of generics and originators and the number of generics entering the market in Austria and in Finland.

Policies targeted: Generic Price Linkage, Generic Substitution, Reference Pricing.

Stakeholders: Austria: Main Association of Austrian Social Security Institutions, pharmaceutical industry, patients. Finland: Finnish Medicines Agency, Pharmaceuticals Pricing Board, Social Insurance Institution, pharmaceutical industry, pharmacies, patients.

Region covered: EURO, Austria and Finland.

\section{Methods}

Study design: Policy evaluation. Time series design was used to estimate changes in price levels.

Time period: 2009-2013.

Setting: Pharmaceuticals used in outpatient care and prescribed either in the public or private sector. Ten active ingredients with high sales in Finland and reimbursable in both countries were included in the analysis.

Interventions: Prices of original products whose patent protection expired during 2010-2012 and generics comparable with them were analysed 6 months before and 12 months after generic entry. Price levels were measured in wholesale prices proportioned to the number of Defined Daily Doses in the package (EUR/DDD).

\section{Results}

One year after generic entry, prices of the originators had fallen, on average, by $46 \%$ in Austria and by $21 \%$ in Finland. Prices of the generics were 66\% lower in Austria and 59\% lower in Finland than prices of the originators before generic entry. The mean number of generics per active ingredient was 6.3 in Austria and 5.1 in Finland.

\section{Conclusions and lessons learned}

Even if uptake of generics is lower in Austria (26\% in volume) than in Finland (36\%), the Austrian pricing system appears to be more efficient to lower prices. Price competition in Finland is probably reduced by a concentrated generic market.

It has been stated that free competition lowers generic prices more efficiently than linking the price of a generic to the price of the originator [2]. That is not necessarily the case. Success of a policy measure also largely depends on how the details of the measure are constructed.

* Correspondence: jaana.martikainen@kela.fi

'Social Insurance Institution, Research Department, Helsinki, 101, Finland

Full list of author information is available at the end of the article 


\section{Authors' details}

'Social Insurance Institution, Research Department, Helsinki, 101, Finland. ${ }^{2}$ WHO Collaborating Centre for Pricing and Reimbursement Policies,

Department of Health Economics, Gesundheit Österreich GmbH (Austrian

Public Health Institute), Vienna, 1010, Austria.

Published: 5 October 2015

\section{References}

1. OECD: Health at a Glance. Europe 2014. OECD Publishing; 2014, 126.

2. Pharmaceutical Sector Inquiry. Final Report. European Commission. Competition DG; 2009.

doi:10.1186/2052-3211-8-S1-P2

Cite this article as: Martikainen et al:: Impact of Generic Price Linkage

System and Reference Price System on prices of pharmaceuticals -

comparison of Austria and Finland. Journal of Pharmaceutical Policy and

Practice 2015 8(Suppl 1):P2.

Submit your next manuscript to BioMed Central and take full advantage of:

- Convenient online submission

- Thorough peer review

- No space constraints or color figure charges

- Immediate publication on acceptance

- Inclusion in PubMed, CAS, Scopus and Google Scholar

- Research which is freely available for redistribution

Submit your manuscript at www.biomedcentral.com/submit 